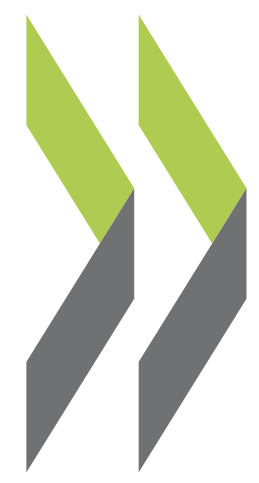

OECD Economics Department Working Papers No. 1015

The US Labour Market

Recovery Following

Wendy Dunn

the Great Recession 
Organisation de Coopération et de Développement Économiques

Organisation for Economic Co-operation and Development

28-Jan-2013

ECONOMICS DEPARTMENT

English - Or. English

THE US LABOUR MARKET RECOVERY FOLLOWING THE GREAT RECESSION

ECONOMICS DEPARTMENT WORKING PAPER No. 1015

By Wendy Dunn

All Economics Department Working Papers are available through OECD's internet website at http://www.oecd.org/eco/Working papers

JT03333628

Complete document available on OLIS in its original format

This document and any map included herein are without prejudice to the status of or sovereignty over any territory, to the delimitation of international frontiers and boundaries and to the name of any territory, city or area. 


\section{ABSTRACT/RESUMÉ}

\section{The US labour market recovery following the great recession}

Although job creation has improved, since the end of the 2007-08 recession, the effects of the recession on the labour market remain severe. Unemployment duration is still extremely high, and many have withdrawn from the labour market altogether. Because the weakness is largely cyclical in nature, policy makers should place a high priority on supporting aggregate demand in the short term. Even so, policies are needed to help individuals return to work, as there is a risk that high long-term unemployment and weak labour market participation could evolve into structural problems. Greater emphasis should be put on activation measures that help individuals search for jobs more effectively or find adequate training programmes. In the longer run, education and training are key to raising the skills and wages of the workforce. In this regard, educational reforms are needed to increase student achievement at all levels. High-quality vocational training can also be used to advance the skills of high-school graduates. College completion rates could be improved by reducing financial and other barriers to education, and enhancing the community college system would be a cost-effective way to provide more individuals with an affordable way to obtain tertiary education. Disability insurance reforms are needed to reduce dependency on these programmes and encourage participation in the workforce.

This Working Paper relates to the 2012 OECD Economic Survey of the United States (www.oecd.org/eco/surveys/United States).

JEL Codes: J2, J6

Key words: Unemployment duration; labour market participation; job creation; human capital; long-term unemployment; structural unemployment; activation policies; hiring subsidies; vocational training; disability

$* * * * * * * * * * * * * * * * * * * * * * * * * * * * * * * * * * * * * * * * * * * * * * *$

\section{La reprise du marché du travail aux États-Unis après la grande récession}

Bien que la création d'emplois ait repris, les effets de la récession se font toujours sentir sur le marché du travail. La durée du chômage reste très élevée et beaucoup ont cessé de chercher un emploi. Compte tenu du caractère largement conjoncturel de cette situation difficile, les autorités devraient donner à court terme la priorité au soutien de la demande. Mais il faut également prendre des mesures pour faciliter le retour à l'emploi, car le risque existe que le niveau élevé du chômage de longue durée et la faiblesse du taux d'activité deviennent des problèmes structurels. Il convient de mettre davantage l'accent sur les mesures d'incitation à la reprise d'un travail afin d'aider les chômeurs à rechercher un emploi ou à trouver des programmes de formation adéquats. À plus long terme, l'éducation et la formation vont jouer un rôle-clé dans l'amélioration des compétences et des salaires de la main-d'œuvre. C'est pourquoi des réformes du système éducatif s'imposent pour améliorer le taux de réussite à tous les niveaux d'études. Une formation professionnelle de qualité peut aussi permettre de développer les compétences des diplômés de l'enseignement secondaire. Réduire les obstacles financiers et autres qui empêchent l'accès à l'éducation serait un moyen d'augmenter les taux de réussite dans l'enseignement supérieur, et améliorer le système des community colleges permettrait, à un coût raisonnable, d'offrir à davantage de personnes la possibilité de suivre des études supérieures dans des conditions financièrement accessibles. Enfin, des réformes de l'assurance invalidité sont nécessaires pour diminuer la dépendance à l'égard de ce régime et encourager le retour sur le marché du travail.

Ce Document de travail se rapporte à l'Étude économique de l'OCDE des États Unis 2012 (www.oecd.org/eco/etudes/Etats Unis).

Codes JEL: J2, J6

Mots-clés: La durée de chômage; la participation au marché du travail; la création de l'emploi; le capital humain; le chômage de long terme; le chômage structurel; les politiques d'activation; les subventions à l'embauche; la formation professionnelle; l'invalidité.

(c) OECD 2013

You can copy, download or print OECD content for your own use, and you can include excerpts from OECD publications, databases an multimedia products in your own documents, presentations, blogs, websites and teaching materials, provided that suitabl acknowledgment of OECD as source and copyright owner is given. All requests for public or commercial use and translation rights shoul be submitted to rights@oecd.org. Requests for permission to photocopy portions of this material for public or commercial use shall bi addressed directly to the Copyright Clearance Centre (CCC) at info@copyright.com or the Centre français d'exploitation du droit de copi (CFC) at contact@cfcopies.com 


\section{TABLE OF CONTENTS}

THE US LABOUR MARKET RECOVERY FOLLOWING THE GREAT RECESSION ..........................5

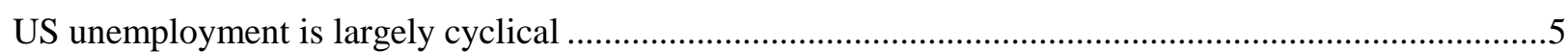

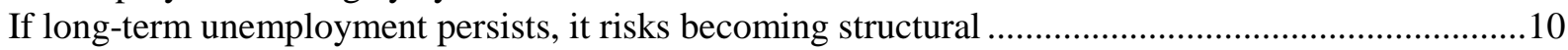

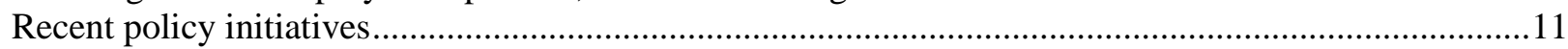

Unemployment benefits should be combined with a more "active" set of re-employment services .....11

Marginal hiring subsidies to further support labour demand should be considered...............................15

Social assistance programmes need additional resources in tough economic times .............................15

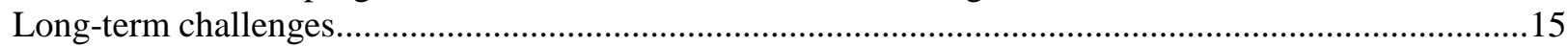



Also of concern is the slow growth in real earnings for the much of the population .............................16

Progress in education attainment is critical to securing future gains in income...................................18

Advance the skills of high school graduates with high-quality vocational training..............................22

Community colleges are a cost-effective means of raising human capital........................................23

Raise completion rates by reducing financial and other barriers.......................................................24

Disability programme reforms are needed to stem the tide of new enrolments ...................................25

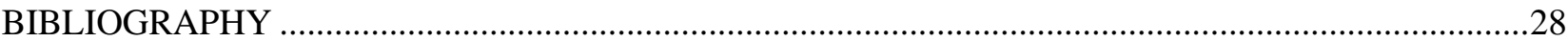

\section{Table}

1. Secondary school achievement in the United States lags well behind that in the best performing countries.

\section{Figures}

1. The unemployment rate has fallen substantially but is still high ......................................................6

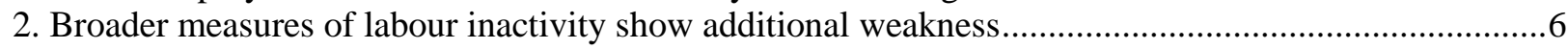

3. Unemployment has fallen more slowly than in previous recoveries .................................................

4. Unemployment rates for some groups are still extremely high .......................................................

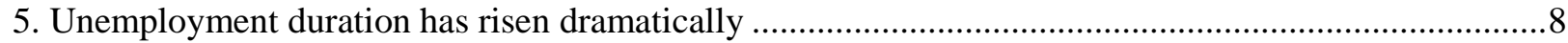

6. The relationship between job vacancies and unemployment changes in severe recessions ..................10

7. Long-duration unemployment has surged in the US and is now close to the level in many OECD

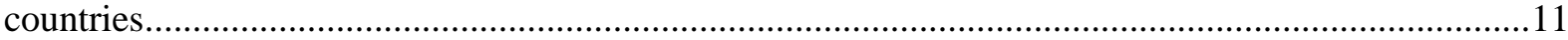

8. Spending on active labour programmes remains low ......................................................................13

9. Demographic changes will continue to push down labour force participation ....................................16

10. Hourly compensation has lagged behind the gains in labour productivity ........................................17

11. Earnings data by gender and educational attainment show a similar pattern of stagnant or declining

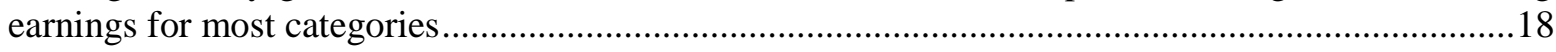

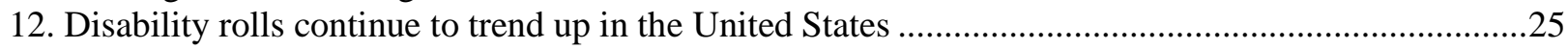

13. Disability enrolments in the Netherlands have dropped noticeably following reforms......................27 


\section{ECO/WKP(2013)7}

\section{Boxes}

Box 1. The costs of unemployment …….......................................................................................... 11

Box 2. Administration proposals to enhance active labour market programmes (ALMPs) .....................14

Box 3. Summary of recommendations for promoting job creation and earnings growth ........................27

This document and any map included herein are without prejudice to the status of or sovereignty over any territory, to the delimitation of international frontiers and boundaries and to the name of any territory, city or area. 
ECO/WKP(2013)7

\title{
THE US LABOUR MARKET RECOVERY FOLLOWING THE GREAT RECESSION ${ }^{1}$
}

\author{
by Wendy Dunn
}

The labour market has strengthened since early 2011, with increased job creation helping to reduce the number of job seekers. Nevertheless, the employment situation has not yet normalised. This chapter first describes labour market developments since the 2008-09 recession and how the current experience compares with historical episodes in the United States and in other OECD countries. The next section documents the sharp rise in unemployment duration, a development that is atypical for the United States. Although the labour market weakness is judged to be largely cyclical in nature and is therefore expected to wane as the economy recovers, the risk is that long-term unemployment could evolve into chronic problems that persist even after aggregate demand has fully recovered. The next section presents several policy recommendations to support job creation in the short term and help individuals return to work. Within this context, the experience of other OECD countries is presented, particularly as it relates to the use of active labour market programmes. Turning to an examination of long-run developments, the chapter describes another worrisome pattern, the decades-long stagnation in real earnings for much of the population. The final sections outline a variety of approaches to address these issues, with an emphasis on measures to promote growth in human capital and encourage participation.

\section{US unemployment is largely cyclical}

The US labour market was hard hit by the Great Recession. The unemployment rate shot up from its pre-crisis level of $4.4 \%$ to a high of almost $10 \%$ in the fourth quarter of 2009 (Figure 1). With aggregate demand growth extremely sluggish in the nearly three years since the peak was recorded, the normalisation of labour market conditions has been a slow process; the current episode marks the first time since the Great Depression that the US unemployment rate has been above $8 \%$ for more than two years. Although the recovery in private-sector job creation thus far has been substantial, the OECD estimates that the Nonaccelerating inflation rate of unemployment (NAIRU) has increased slightly, to around $6 \%$, and that cyclical unemployment is still more than $2 \%$ of the labour force. However, structural unemployment could already have risen more than this estimate would suggest, and there is a risk that it could increase still further given the high levels of long-term unemployment.

1 This paper was originally produced for the 2012 OECD Economic Survey of the United States and published in June 2012 under the authority of the Economic and Development Review Committee (EDRC) of the OECD. Wendy Dunn is an Economist in the OECD Economics Department. I would like to thank David Carey, Oliver Denk, Paul Swaim, Andrew Wyckoff, Andrew Dean, Robert Ford, Patrick Lenain, and members of the EDRC for valuable comments and discussions. I am also grateful to Valery Dugain for technical assistance and to Heloise Wickramanayake for secretarial assistance. 
Figure 1. The unemployment rate has fallen substantially but is still high

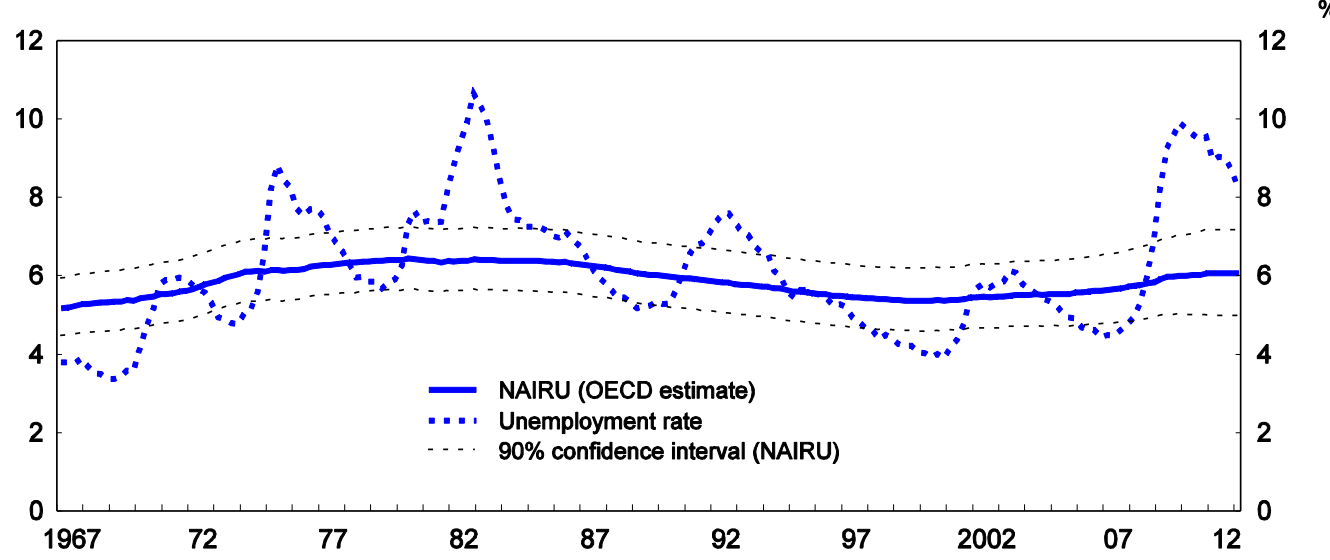

Note: More information about the NAIRU can be found in Guichard, S. and Rusticelli, E. (2011)

Source: OECD, Economic Outlook 91 and Analytical database and OECD calculations.

Furthermore, the headline measure of unemployment does not incorporate the fact that ongoing weakness in labour demand has led some individuals to give up their job search and exit the labour force. Labour market participation in the United States typically exhibits a moderate degree of cyclicality (Aaronson et al., 2006a), yet it has edged down further thus far in the recovery (Van Zandweghe, 2012). Alternative measures of unemployment that include discouraged workers and those marginally attached to the workforce thus provide a broader depiction of the weak situation of the labour market (Figure 2).

Figure 2. Broader measures of labour inactivity show additional weakness

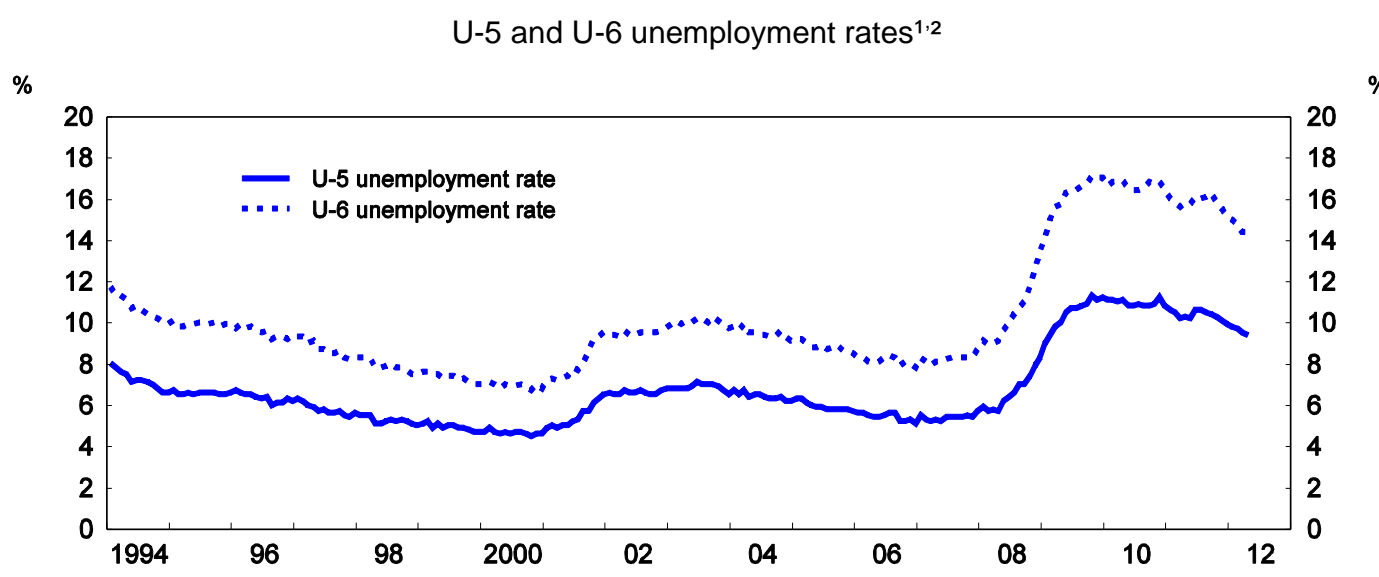

1. U-5 Total unemployed, plus discouraged workers, plus all other persons marginally attached to the labour force, as a per cent of the civilian labour force plus all persons marginally attached to the labour force.

2. U-6 Total unemployed, plus all persons marginally attached to the labour force, plus total employed part time for economic reasons, as a per cent of the civilian labour force plus all persons marginally attached to the labour force.

Source: U.S. Bureau of Labor Statistics, Current Population Survey 2012.

As is now well known, the contraction in output and employment during the recession was large in relation to most earlier US cycles, and the recovery in activity has been more protracted than in most earlier episodes (Figure 3, Panel A). The impact of the financial crisis on the US unemployment rate was also large from an international perspective (Figure 3, Panel B). In the major European countries, relatively 
strong employment protection laws prevented businesses from shedding employment as sharply as businesses in the United States, and governments encouraged firms to keep workers on the job through various incentive schemes. As a result, productivity in these countries fell over the recession, while employment declined relatively little. Participation rates also held up better in these countries than in the United States.

Figure 3. Unemployment has fallen more slowly than in previous recoveries
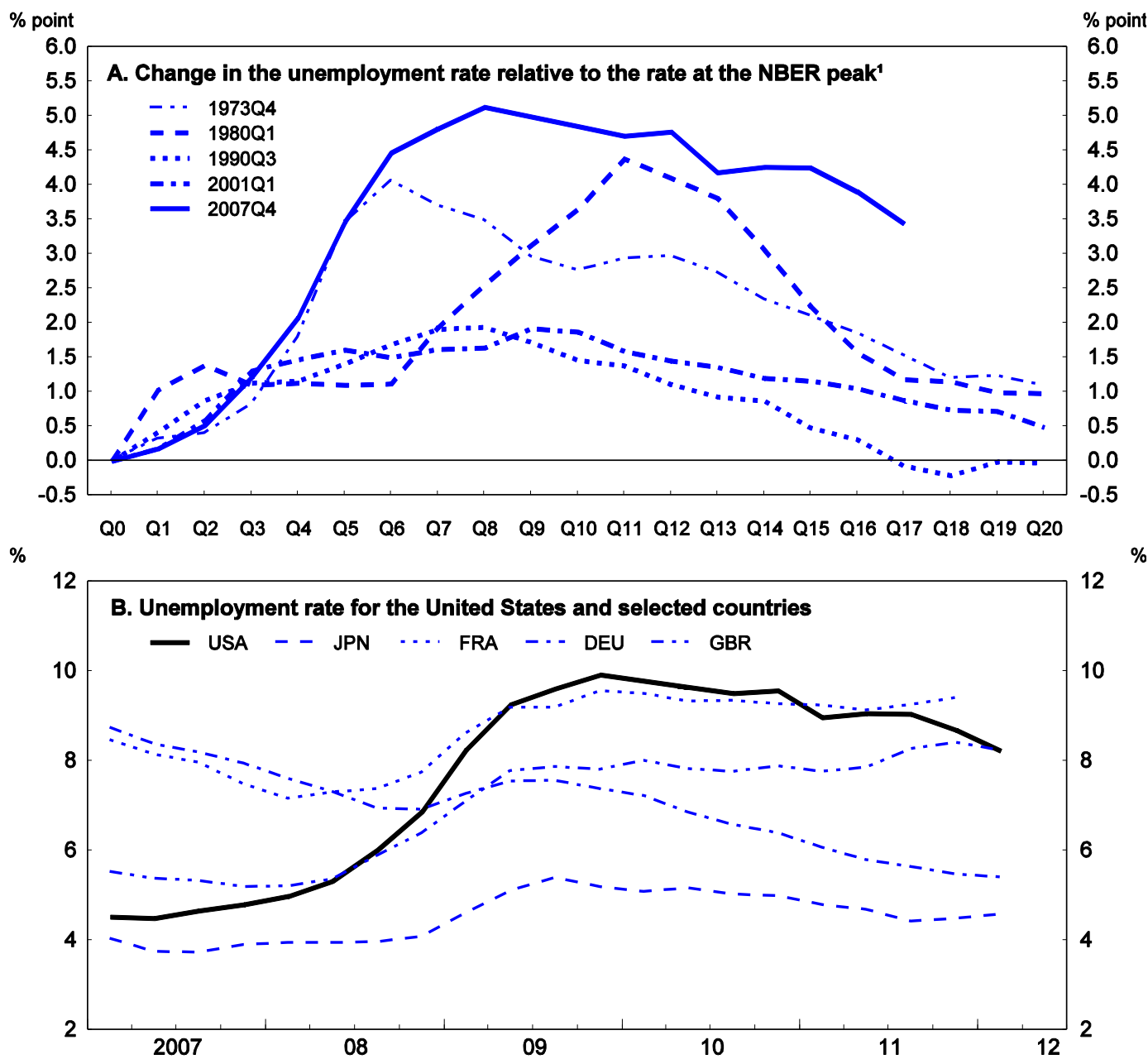

1. Based on NBER-defined recession dates. Peak in 1981 Q3 not shown separately.

Source: OECD, Analytical Database.

Indeed, even with the significant improvement in aggregate employment during the recovery to date, unemployment rates for certain sub-groups of the US population have remained extremely high (Figure 4). In March 2012, the unemployment rate for those without a high-school diploma was nearly $13 \%$, the rate for youth (aged 16 to 19) was 25\%, and the jobless rate for African American youth was still close to $40 \%$. 
Figure 4. Unemployment rates for some groups are still extremely high

$\%$

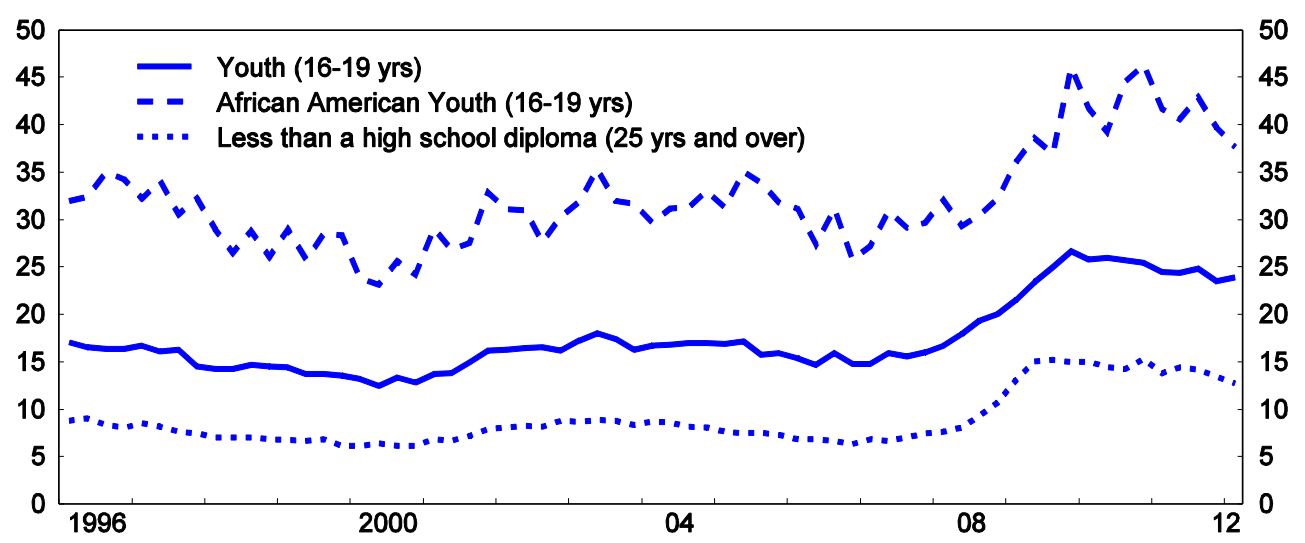

Source: U.S. Bureau of Labor Statistics, Current Population Survey 2012.

Another development in recent years that is unusual for the United States is the dramatic rise in the duration of unemployment (Figure 5). From 2003 to 2007, prior to the onset of the crisis, the median duration of periods of unemployment reported in the BLS survey of households was about 9 weeks. By early 2010, this figure had risen to almost 26 weeks, though since then it has edged down to around 20 weeks.

Figure 5. The duration of unemployment duration has risen dramatically

In median weeks



Source: U.S. Bureau of Labor Statistics, Current Population database Survey 2012.

Although the rise in unemployment duration over this period can be attributed largely to the severe contraction in aggregate activity and the accordant effects on labour demand, other factors have also contributed to the increase. As documented by Aaronson et al. (2010), the gradual shift in the composition of the workforce toward older workers has pushed up unemployment duration by a small amount. Young people tend to experience comparatively short unemployment spells because they move into and out of the labour force more frequently than older individuals, and older workers who lose their jobs typically take longer to find a new job than do younger workers. 
Some critics of the recent extensions to unemployment insurance (UI) benefits have argued that, by raising recipients' reservation wages, UI benefits might push down labour supply and thus contribute to a higher duration of unemployment. But one must also consider that, in the absence of UI benefits, many of those who are unable to find work might have given up searching and dropped out of the labour force altogether. By encouraging continued job search activity, UI benefits therefore may actually raise the re-employment prospects of displaced workers. Supporting this view, Krueger and Mueller (2011) find that that increased time spent on job search is associated with faster exits from UI benefit dependency. Indeed, given the especially weak labour demand conditions in the current episode, the positive effects of encouraging labour supply are likely to be larger than usual.

Some economists have theorized that the unusually sharp rise in unemployment duration over the Great Recession may be, in part, a consequence of the burst in the housing market bubble, which led to a rise in mismatches between labour supply and demand (e.g. Estevão and Tsounta, 2011). A popular argument in this vein is that the housing boom diverted an unusually large number of workers into construction-related jobs, and these jobs call for a set of skills that are not easily transferable to other careers. With construction activity severely reduced for an extended period, there may exist an unusually large pool of workers whose skills are not well suited for the existing job openings.

Others have argued that the housing market downturn may have led to labour matching problems by constraining the mobility of home owners, who are unable to relocate to where there are job openings or higher wages because they have negative home equity, or because they anticipate serious difficulties in selling their current home (Chan, 2001; Karahan and Ree, 2011). Given the severe contraction in the housing market, the potential magnitude of this problem is significant. Estimates from Corelogic indicate that roughly a quarter of the 50 million residential mortgages in the United States are currently "under water", meaning that the amount owed exceeds the value of the home.

Nevertheless, the empirical evidence suggests that the two sources of mismatches mentioned above are small, and that the housing market contraction has played only a limited role in the labour matching inefficiencies observed during the current episode (Molloy et al., 2011). Broadly speaking, research studies indicate that a rise in the rate of labour mismatches is a normal symptom of the business cycle that eventually unwinds as the economy recovers. For instance, Elsby et al. (2010) found that labour-market developments during the Great Recession were similar to the patterns observed in previous cycles, and that the rise in unemployment duration was largely consistent with the severity of the contraction and with the particularly sharp rise in layoffs over the period. Indeed, as Haltiwanger (2011) noted, the dynamic process of job creation, destruction, and reallocation is a large and significant component of any healthy, productive economy.

A comparison of movements in the Beveridge curve over various cycles provides support to this view. The Beveridge curve illustrates the contemporaneous relationship between the number of job vacancies and unemployment. It follows from a basic job search model, and captures the idea that the rate of flow of workers from unemployment to employment is determined by the number of job vacancies that exist relative to the number of job seekers (Mortensen and Pissarides, 1994). Theoretical explanations for the existence of unfilled vacancies involve various frictions that result in inefficiencies in matching labour supply and demand. A graphical representation of the Beveridge curve is convex and downward sloping, owing to the fact that in prosperous times the unemployment rate is low and unfilled vacancies are high, while in bad times there are few vacancies and a high rate of unemployment. A given curve is therefore the locus of vacancy rates and unemployment that are consistent with a stable unemployment rate given the flows that they induce.

Consistent with the theory, empirical observations of the Beveridge curve using data from the Job Openings and Labor Turnover (JOLTS) survey exhibit a downward sloping curve (Figure 6). Notably, 
however, observations since 2009 seem to indicate an outward shift in the curve. As the economy recovered and the job vacancy rate began to increase, the unemployment rate failed to decline as fast as one would expect if the underlying relationship between vacancies and the unemployment rate had remained stable. However, a comparison with the severe economic downturns in 1973 and 1979 points to a similar experience: The Beveridge curve shifted outward, but the move proved to be temporary, as the curve eventually shifted back inward during the subsequent recoveries. Thus, historical experience suggests that roughly the same pattern will evolve in the current cycle.

Figure 6. The relationship between job vacancies and unemployment changes in severe recessions



1. The vacancy rate from 1973 Q4 to 1983 Q4 is given by an index of help-wanted advertisements divided by the labour force.

Source: For the unemployment rate, US Bureau of Labor Statistics; Current Population Survey 2012. For the job vacancy rates, US Bureau of Labor Statistics; Jobs Openings and Labor Turnover Survey, and Conference Board and Barnichon (2010). Reproduced from Yellen (2012).

\section{If long-term unemployment persists, it risks becoming structural}

A direct consequence of the severe labour market contraction is that the incidence of long-term unemployment in the United States has surged, from a pre-crisis level well below that observed in most OECD countries, to a level that is close to that in many European countries and Japan (Figure 7). A number of other OECD countries have recorded large increases in long-term unemployment in recent decades, and their experience shows that long-term joblessness can become entrenched and create very large costs both for the affected workers and for the society as a whole (Box 1). Although the current weakness in the US labour market is mostly cyclical in nature, there is nevertheless a significant risk that long-term unemployment could evolve into chronic problems that persist long after the shortfall in aggregate demand has been eliminated. To avoid this outcome, policy makers should place a high priority on supporting the recovery in the short term and reversing the rise in long-term unemployment. 
Figure 7. US long-duration unemployment has surged and is now close to the level in many OECD countries

Persons unemployed 12 months and longer as a percentage of total unemployment ${ }^{1}, 2007 \mathrm{Q} 3-2011 \mathrm{Q} 3$

$\%$



1. Data are not seasonally adjusted. OECD is the weighted average of 32 OECD countries excluding Chile and Korea.

The results for Japan exclude three prefectures (Iwate, Miyagi and Fukushima) struck by the Great East Japan Earthquake, where the survey operation is suspended since March 2011.

Source: OECD calculations based on quarterly national Labour Force Surveys.

\section{Box 1. The costs of unemployment}

Research has shown that periods of unemployment can have large and long-lasting negative effects on job losers. For example, recent research by Davis and von Wachter (2011) examined male workers age 50 or younger with at least three years of tenure who lost their jobs in mass layoffs (defined as employment decreases of at least $30 \%$ over two years at their place of employment) between 1980 and 2005 . The authors found that that job displacement led to a loss of 1.7 years of earnings, on average, accumulated over 20 years. Moreover, the earnings losses varied depending on when the job loss occurred; job displacement led to an average accumulated earnings loss of 2.8 years if the job was lost when the unemployment rate was above $8 \%$, but the earnings loss was only half as large-1.4 years-if the job was lost when the unemployment rate was below $6 \%$.

Long spells of unemployment can also permanently reduce employment prospects because workers' skills and work motivation tend to degrade over time, and employers often prefer to hire candidates with recent work experience (Blanchard and Diamond, 1994).

Other studies have demonstrated that periods of unemployment have detrimental effects on the physical or mental health and sense of well-being of individuals (e.g., Krueger and Mueller, 2011; Sullivan and von Wachter, 2009). Marriage rates, labour mobility, and rates of household formation are all lower when unemployment is high.

Finally, unemployment imposes significant social costs because some job losers will drift into permanent benefit dependency, for example by moving onto disability benefits after they have exhausted their entitlement to UI benefits (Autor, 2011).

\section{Recent policy initiatives}

\section{Unemployment benefits should be combined with a more "active" set of re-employment services}

During the latest recession, the federal government moved decisively to expand the income support available to the long-term unemployed via the unemployment insurance (UI) system. Existing law had provided for up to 26 weeks of benefits, plus up to 20 additional weeks of extended benefits in states with relatively high unemployment rates. Beginning with the American Recovery and Reinvestment Act (ARRA) in 2009, federal support was strengthened by increasing both the benefit levels and the maximum 
duration of eligibility (federal benefits take effect when state aid expires). The period of eligibility for unemployment benefits was increased in steps from 26 weeks to 99 weeks. This year, the maximum period of eligibility moves down gradually to 73 weeks.

These emergency unemployment benefits were a welcome form of fiscal support as they provided a much-needed cushion for many of the most financially stressed households. In addition, from a macroeconomic perspective the UI benefits represent a relatively effective tool for stimulating aggregate demand and boosting economic activity, because benefit recipients are likely to be liquidity constrained and have a high propensity to consume (Johnson et al., 2006; Parker et al., 2011). For both of these reasons, policy makers should consider keeping these programmes in place until the scope of joblessness is reduced further. The most recent unemployment figures reinforce the argument that a significant portion of the US population is still in critical need of income support: Household survey data for April 2012 showed that 12.5 million individuals are unemployed and another 2.4 million are not counted in the labour force but have reported that they want a job and have looked for work in the past year. In addition, 7.7 million employed individuals are working only part-time for economic reasons, such as an inability to find full-time work.

To minimise the risk of an emergence of negative effects on labour supply, the eligibility period for UI benefits could be gradually adjusted back toward the pre-recession baseline of 26 weeks as the labour market improves. Ideally, the timing of the reductions in the eligibility period would be dependent on the progress of one or more aggregate economic indicators, such as the unemployment rate. It may also be useful to consider gradually reducing the replacement rate for individual benefit recipients as their unemployment duration progresses beyond a certain threshold. Previous OECD research suggests this type of rule can help incentivize job search and speed the return to work (OECD, 2011a).

It is important, however, that the "passive" forms of unemployment assistance like cash benefits be offered in tandem with a more "active" set of re-employment services that can connect job seekers with job opportunities, facilitate job search, and guide individuals towards training and education. Job counsellors should be used to provide active case management, especially to those who appear to be at an elevated risk of becoming structurally unemployed. There is ample evidence that these types of active labour market programmes (ALMPs) can play a useful role in speeding the return to work for unemployed job seekers (OECD, 2011a). Moreover, re-employment assistance is likely to be especially important for the current pool of long-term unemployed, because job-search prospects have been shown to deteriorate as jobless spells lengthen (Krueger and Mueller, 2011).

Important insights into the effects of re-employment services can be gleaned from the experiences of other OECD countries that have used these types of programmes. During the 1990s, benefit dependency rates in many European countries tended to drift upwards (and employment rates downwards) when longduration income support benefits were made available to working-age people without the accompaniment of ALMPs. However, many of these countries later managed to reverse some or all of those increases by reforming their benefit systems and tying them to a more effective set of ALMPs. Previous OECD research has demonstrated that while measures to trim excessively generous benefits were important in some countries, the implementation of effective activation strategies for benefit recipients played an important role in all cases (OECD, 2006). The experience of these countries also showed that successful policies need to be structured so that benefit recipients not only are offered re-employment services but also are required to participate in job search, training or employment programmes, with this requirement being enforced by "return-to-work contracts" and regular contacts between recipients and case workers.

Relative to other OECD countries, the United States spends very little on active labour market programmes (OECD, 2011a). Estimates by the OECD indicate that total US spending on ALMPs in 2007 amounted to $0.13 \%$ of GDP, far lower than the levels of up to $1 \%$ of GDP observed in many other 
OECD countries, including those with similar unemployment rates, and those, like Canada and the United Kingdom, with similar labour market institutions (Figure 8). US spending on these programmes is also low from a historical perspective; over the 20 years prior to the recession, spending on ALMPs in the United States declined from $0.24 \%$ of GDP to $0.13 \%$. These reductions left the US system ill prepared to cope with the subsequent surge in the number of unemployed and the sharp rise in the risk that job losers fall into long-term unemployment. Low activation spending is not as important when labour market conditions are reasonably buoyant, but it needs to be ramped up again to meet the current unemployment challenge.

Figure 8. Spending on active labour programmes remains low ${ }^{1,2}$

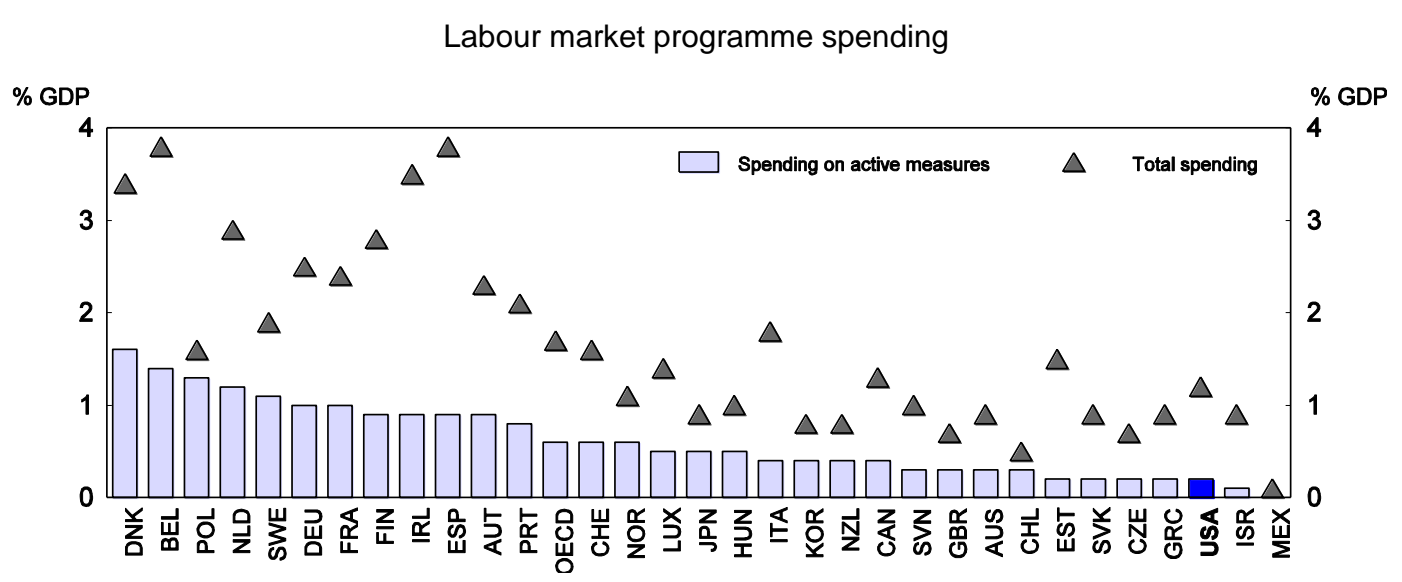

1. Countries are shown in descending order of active labour market spending in 2009.

2. Data for Greece exclude spending on Public Employment Services (PES).

Source: OECD Labour Market Programmes Database.

During the recession, the US government did reinforce the re-employment assistance available to the unemployed. The American Recovery and Reinvestment Act included additional funds for states to expand the services provided by One-Stop-Career-Centers; however, the increase was quite small in relation to the sharp rise in unemployment, likely owing to intense budgetary pressures, especially at the state and local level, and to the inherent difficulty of quickly scaling up effective re-employment services. Nevertheless, significantly more resources are needed to develop an effective activation system that will address the needs of the many individuals still facing joblessness. The Administration has taken several steps in this regard. The Middle Class Tax Relief and Job Creation Act of 2012 added a requirement that all Extended Unemployment Compensation (EUC) recipients receive eligibility assessments and re-employment services, including labour market information, skills assessments and a re-employment plan. Moreover, the Act included measures that will move the unemployment compensation system in the direction of becoming a re-employment system, such as allowing the flexible use of unemployment benefits by individuals seeking to launch their own businesses or who are undergoing short-term, on-the-job training. The Administration's FY 2013 budget proposal included several other measures aimed at developing a more comprehensive activation system, and these should be implemented in full. Although funding increases may be difficult in the current fiscal environment, the investments should be considered a high policy priority that would have long-term payoff in terms of reducing the labour market marginalisation of increasing numbers of workers.

The set of services provided at these centres also needs to be broadened to address a larger set of needs. For example, while a variety of re-employment services exist to help individuals conduct a job search, there are relatively few programmes that can guide individuals toward opportunities for acquiring 
training or education that will result in high quality re-employment. Even workers with a well-established track record on the job may become unemployed because of changes in economic conditions in the business or industry in which they work, and for many of these individuals, it would make sense to obtain training or education for a different career with a higher market value. In addition, individuals seeking to invest in education or training need access to objective, easy-to-access information on how graduates from various programmes fare in the labour market.

Efforts to consolidate and streamline the existing programmes that provide training and employment services are also encouraged, as the current system of services is very piecemeal across many levels of government. The development of a coherent system for activation services could ensure that scarce fiscal resources can be directed toward the programmes that will generate the highest return. In addition, many states and localities already have implemented successful programmes that could be scaled up or adopted elsewhere, but additional effort is needed to gather information on the lessons learned and to implement the more successful approaches more broadly.

\section{Box 2. Administration proposals to enhance active labour market programmes (ALMPs)}

The American Recovery and Reinvestment Act (ARRA) of 2009 included additional funds for states to expand the services provided by One-Stop career centers, and the Middle Class Tax Relief and Job Creation Act of 2012 added a requirement that all Extended Unemployment Compensation (EUC) recipients receive eligibility assessments and re-employment services, including labour market information, skills assessments and a re-employment plan. In addition, the Administration has a variety of proposals to further enhance ALMPs. Details are included in the American Jobs Act (AJA) proposal, the Administration's FY 2013 budget plan, and other White House press releases (White House, 2011; White House, 2012a; White House, 2012b).

Broadly speaking, the Administration's proposals focus on two objectives: i) helping workers acquire skills needed for high-value jobs, and ii) reforming the nation's re-employment system. Many of the proposed measures would mark significant steps toward a more cohesive set of activation services, and their implementation is therefore recommended.

A major component of the Administration's plan is to create a new Universal Displaced Worker Program (UDWP) that would streamline training and employment services for dislocated workers. The programme would be designed to offer a broad set of services and provide displaced workers with job-search assistance and access to training. Various forms of financial support for displaced workers would also be administered through this programme:

- Individuals could receive up to USD 4000 per year for up to two years to pursue technical training in the skills necessary for jobs outside their previous career field. Those enrolled in training or looking for a job would also receive a weekly stipend for child care, transportation, and other expenses for up to 78 weeks, in addition to 26 weeks of UI benefits.

- $\quad$ Displaced workers would receive allowances of up to USD 1250 each for job search and relocation.

- Workers aged 50 or older who obtain new, full-time employment at wages of less than USD 50000 would receive wage insurance for up to two years to partially offset earnings losses in new jobs that pay less than their previous jobs.

Another major proposed initiative is the creation of an American Jobs Center network, an effort to connect the vast array of employment and centers that currently exist at different levels of government into one system of resources. Online resources for job seekers would also be consolidated, with a goal of providing a single point of access for information to help people find a job, identify training programmes, and receive counseling and case management services. 


\section{Marginal hiring subsidies to further support labour demand should be considered}

Subsidies to employers for recruiting new employees are another effective way to raise the jobs intensity of output growth, and such measures should be considered in the short run. In 2010, the Hiring Incentives to Restore Employment (HIRE) Act offered a tax credit to employers who hired individuals who had been unemployed more than 6 months, but the take-up rates for this credit were disappointing, partly because of the modest size of the credit, and the subsidy expired before the pace of job creation had become self-sustaining.

The tax credit proposed in the American Jobs Act (AJA) appears more promising than the HIRE Act subsidy because it is targeted on net increases in payrolls, and research conducted by the OECD and others indicates that these types of marginal subsidies can indeed stimulate job creation in a depressed economy (OECD, 2011a; Neumark, 2011). The AJA tax credit could be made still more cost-effective, however, if it were limited to net increases in employment and not the wage bill, as labour supply on the employment margin is much more responsive to wages than labour supply on the hours margin. A second component of the original AJA proposal, not retained as part of the Administration's FY 2013 budget, was a separate USD 4000 credit for hiring new employees who had previously been unemployed more than 6 months. But targeted credits like these may transmit negative signals to employers that offset the positive effects of the credit (Dickert-Conlin and Holtz-Eakin, 2000).

\section{Social assistance programmes need additional resources in tough economic times}

The latest recession has also exposed inadequacies in the responsiveness of other social assistance programmes in the United States. In particular, as reported by the Center on Budget and Policy Priorities (CBPP) in July 2011, federal funding for the Temporary Assistance to Needy Families (TANF) programme is not designed to rise when caseloads increase in adverse economic conditions. Indeed, TANF's annual block grant funding level has been frozen since its creation 15 years ago and inflation has eroded $28 \%$ of its real value. This stands in contrast to TANF's predecessor, Aid to Families with Dependent Children (AFDC), for which federal funding rose automatically during economic downturns as state caseloads expanded, enabling states to respond to rising hardship and poverty (Pavetti and Schott, 2011). To make matters worse, many states facing budgetary pressures cut benefits to TANF recipients sharply in recent years, even as the number of individuals in need of assistance was surging. According to the CBPP, these state-level cuts affected 700000 low-income families, including 1.3 million children.

TANF should therefore be made more responsive to economic conditions. The Supplemental Nutrition Assistance Program (SNAP, or food stamp) can provide a useful model, as this programme responded much more effectively to the downturn. SNAP benefits are fully federally funded and counter-cyclical, providing additional funding when the need for food assistance rises as it did during the recent recession. Even with these modifications, the safety net for American households would still be modest by comparison with other advanced OECD economies.

\section{Long-term challenges}

\section{Labour force participation has declined}

Several long-standing labour market issues will need to be confronted even after the economy has returned to health. The first of these is the decline in the rate of labour force participation. Demographic factors have been putting downward pressure on participation, and thus labour supply, for more than a decade (Aaronson et al., 2006a; Hotchkiss, 2009). Most importantly, the ageing of baby-boom generation means that an increasing share of the population is entering its low-participation years. In addition, after rising steeply beginning in the 1970s, the labour-force participation of women has levelled off and even 
edged down a bit. Other sub-groups of the population, especially youth, have also recorded trend declines since the early 2000s, and these patterns were only exacerbated by the Great Recession. Indeed, nearly half of the sharp decline in youth employment over the past four years has appeared as withdrawals from the labour force rather than increases in unemployment.

While rising school enrolments can partly explain the lower rates of labour force participation for youth, other contributing factors, such as the increased concentration of jobs at the extreme ends of the skills distribution, are much more worrisome (Aaronson et al., 2006b; Smith, 2011). Moreover, given the ongoing changes in the demographic composition of the population, Toossi (2012) and others have projected substantial further declines in the labour force participation rate in the years ahead (Figure 9), which will present challenges to the government in meeting its long-term fiscal objectives.

Figure 19. Demographic changes will continue to push down labour force participation

Actual and projected participation rate, age 16 and over

$\%$

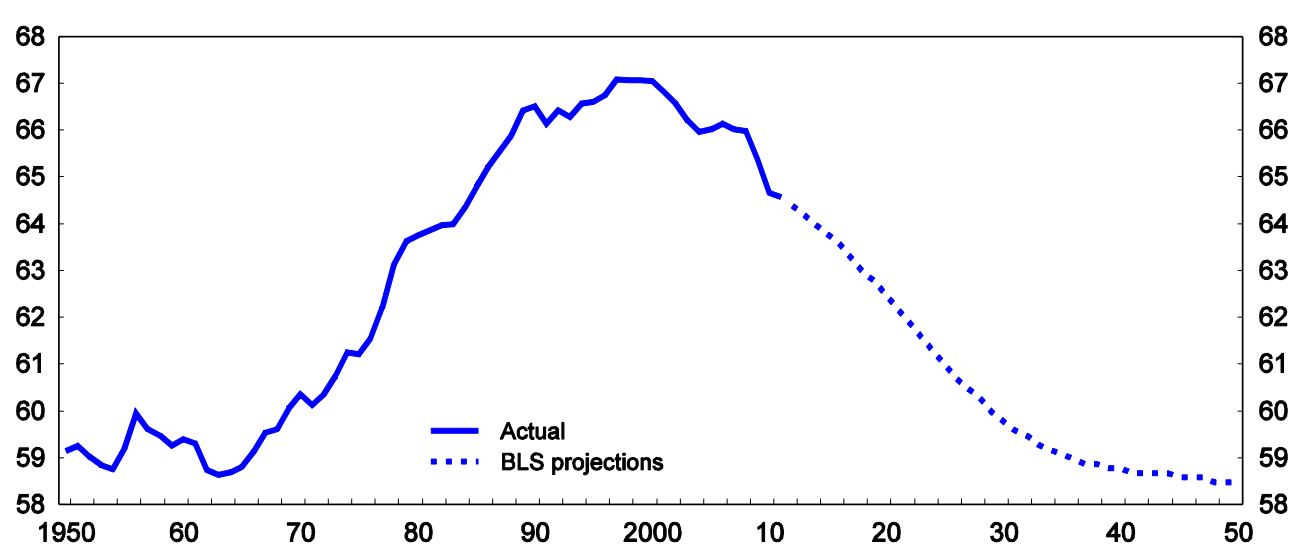

Source: U.S. Bureau of Labor Statistics projections through 2050 provided by Toossi (2012).

\section{Also of concern is the slow growth in real earnings for the much of the population}

Another underlying structural issue is the slow growth in real earnings for a large portion of the population. Through the 1960s and 1970s, earnings per worker grew at a robust rate, generating increases in standards of living for most of the US population (Figure 10). But since the early 1980s, real compensation growth has lagged behind the gains in labour productivity, partly reflecting higher growth in consumer prices than in producer prices. 
Figure 10. Hourly compensation has lagged behind the gains in labour productivity

Index base $1947=100$

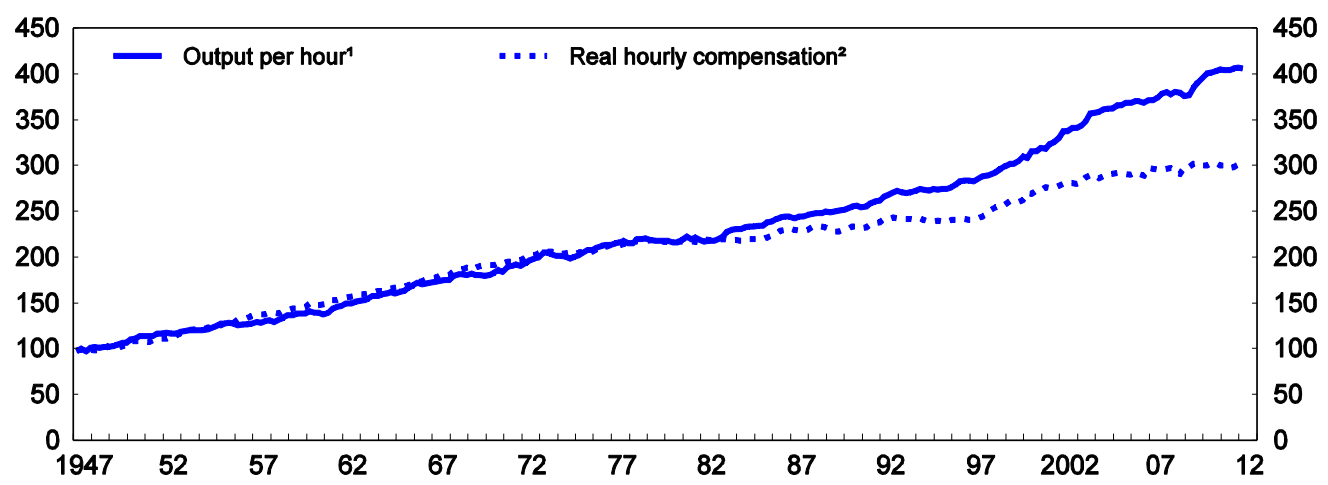

1. Output data are based on estimates of non-farm business output in constant dollars from the National Income and Product Accounts. Hours data are from the Bureau of Labor Statistics.

2. Compensation includes wages and salaries of employees plus employer's contributions for social insurance and private benefit plans, and it reflects the adjustment of hourly compensation for changes in consumer prices. The price changes for recent quarters are based on the BLS Consumer Price Index for all urban consumers (CPI-U). For earlier periods, consumer prices are based on the BLS Consumer Price Index research series (CPI-U-RS).

Source: U.S. Bureau of Labor Statistics, Productivity and Cost database 2012.

Real earnings by gender and level of education also have exhibited a pattern of lacklustre growth, particularly for the lowest education groups (Figure 11). Earnings of males with at least a bachelor's degree have held fairly steady, while those of the other three groups have declined. Earnings growth for females who have a college degree has far outpaced the gains for women with lower education attainment. These patterns reflect a large and increasing wage premium for college graduates: Goldin and Katz (2008) estimate that the college/high school wage premium surged from $35 \%$ in 1980 to $60 \%$ in 2005 . In addition, college graduates, face much lower risk of becoming unemployed. These dynamics are not unique to the United States: Across many of the high-income countries of the OECD, demand for highly-skilled labour is rising faster than supply (ibid). These issues are discussed further in Chapter 2. 
Figure 11. Earnings data by gender and educational attainment show a similar pattern of stagnant or declining earnings for most categories

In 2010 dollars
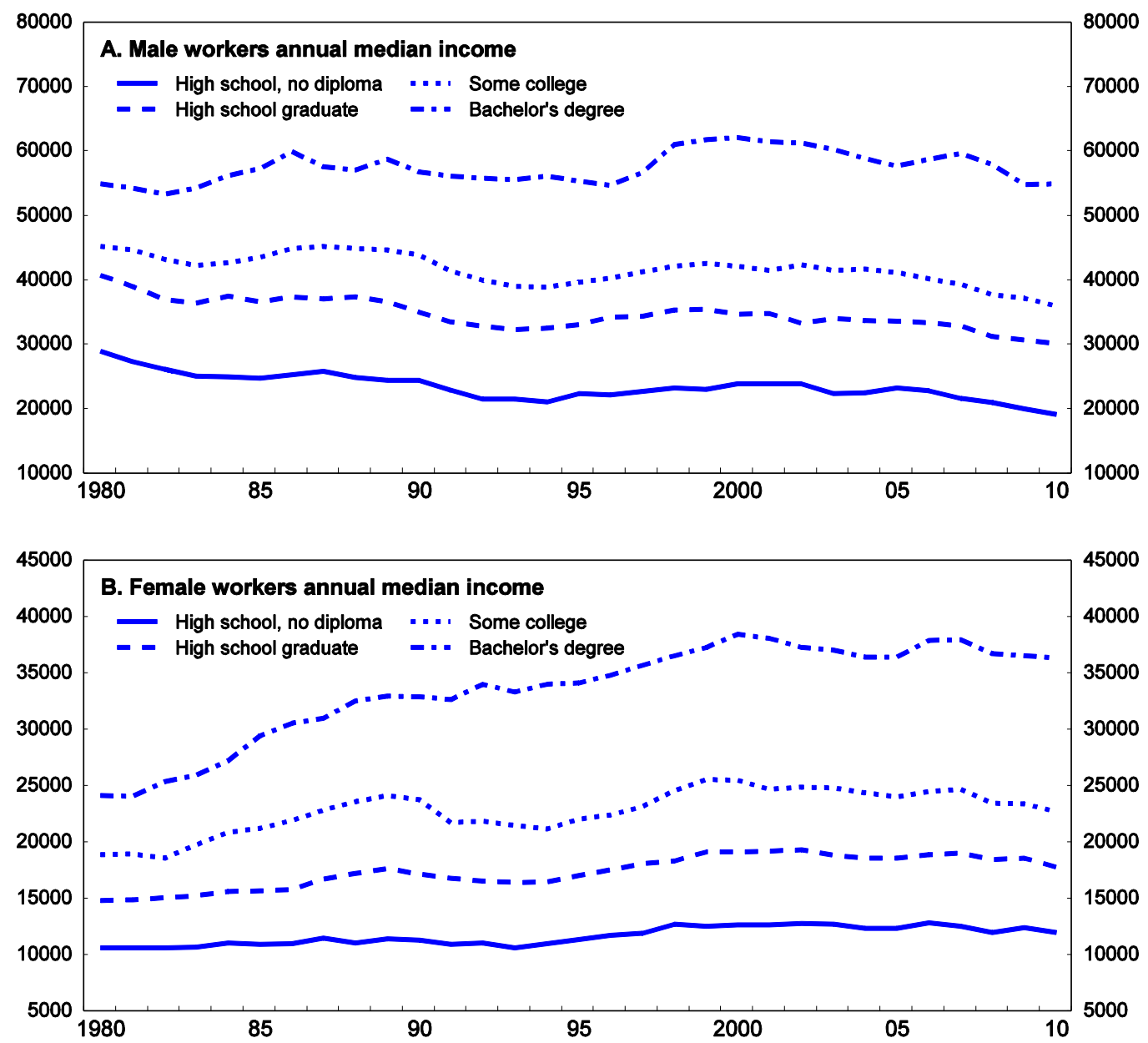

Source: U.S. Census Bureau, Current Population Survey, Annual Social and Economic Supplements 2012.

\section{Progress in education attainment is critical to securing future gains in income}

Progress in educational attainment and achievement is therefore critical to securing future gains in income and narrowing income inequality. Based on practices in the top-performing countries in the PISA study, a variety of secondary school education reforms are needed to upgrade US achievement towards the top levels (OECD, 2011b). As a percentage of GDP, the United States spends much more on education than most other OECD countries, yet achievement of 15-year olds in the United States is just slightly above the OECD average in reading, average in science, and slightly below average in mathematics (Table 1). Furthermore, socio-economic background has a much greater impact on student outcomes in the United States than it does in most other countries, resulting in much wasted talent. The United States cannot afford a school system with such mediocre outcomes if it wants to preserve its place amongst the richest knowledge-based economies.

The potential economic gains from raising education achievement are substantial. A recent study by the OECD and the Hoover Institution at Stanford University (OECD, 2010d) suggests that a boost in 
US PISA scores of just 25 points over the next 20 years - which corresponds to the performance gains that some countries achieved between 2000 and 2009 alone - would imply a cumulated gain of USD 41 trillion for the US economy over the lifetime of the generation born in 2010 (as evaluated at the start of the reform in terms of the present value of future improvements in GDP). Longitudinal studies have also demonstrated that student performance at school is a good indicator of subsequent successful education and labourmarket pathways (OECD, 2010b). 
Table 1. Secondary school achievement in the United States lags well behind that in the best performing countries

\begin{tabular}{|c|c|c|c|c|c|c|c|c|c|c|c|c|c|c|c|}
\hline & \multirow{2}{*}{\multicolumn{10}{|c|}{ Quality }} & \multirow{3}{*}{$\begin{array}{c}\text { Equity } \\
\text { PISA } 2009 \\
\text { Results, }{ }^{1} \text { Table } \\
\text { II.3.2 }\end{array}$} & \multirow{3}{*}{$\begin{array}{c}\text { Coherence } \\
\text { PISA } 2009 \\
\text { Results, }{ }^{1} \text { Table } \\
\text { II.5.1 }\end{array}$} & \multirow{3}{*}{$\begin{array}{c}\text { Efficiency } \\
\text { EAG }^{2}{ }^{\text {Table }} \\
\text { B1.2 }\end{array}$} & \multirow{3}{*}{$\begin{array}{c}\text { Income } \\
\text { EAG, }^{2} \text { Table } \\
\text { X2.1 }\end{array}$} & \multirow{3}{*}{$\begin{array}{c}\text { Equality } \\
\text { PISA } 2009 \\
\text { Results, } \\
\text { Table II.1.2 }\end{array}$} \\
\hline & & & & & & & & & & & & & & & \\
\hline & \multicolumn{2}{|c|}{$\begin{array}{l}\text { PISA } 2009 \\
\text { Results, } \\
\text { Table V2.1 }\end{array}$} & \multicolumn{2}{|c|}{$\begin{array}{l}\text { PISA } 2009 \text { Results, }{ }^{1} \\
\text { Table V.2.1 }\end{array}$} & \multicolumn{2}{|c|}{$\begin{array}{l}\text { PISA } 2009 \text { Results, }{ }^{1} \\
\text { Table V.2.1 }\end{array}$} & \multicolumn{2}{|c|}{$\begin{array}{c}\text { PISA } 2009 \text { Results, }^{1} \\
\text { Table I.3.3 }\end{array}$} & \multicolumn{2}{|c|}{$\begin{array}{c}\text { PISA } 2009 \\
\text { Results, }{ }^{1} \text { Table } \\
\text { I.3.6 }\end{array}$} & & & & & \\
\hline & \multicolumn{2}{|c|}{$\begin{array}{l}\text { Mean PISA score } \\
\text { on the reading } \\
\text { scale } 2009\end{array}$} & \multicolumn{2}{|c|}{$\begin{array}{c}\text { Mean PISA score on } \\
\text { the reading scale } \\
2000\end{array}$} & \multicolumn{2}{|c|}{$\begin{array}{c}\text { PISA score } \\
\text { difference in reading } \\
\text { between } 2000 \text { and } \\
2009\end{array}$} & \multicolumn{2}{|c|}{$\begin{array}{l}\text { Mean PISA score on } \\
\text { the mathematics } \\
\text { scale } 2009\end{array}$} & \multicolumn{2}{|c|}{$\begin{array}{l}\text { Mean PISA score } \\
\text { on the science } \\
\text { scale } 2009\end{array}$} & $\begin{array}{l}\text { Percentage of the } \\
\text { variance in student } \\
\text { performance } \\
\text { explained by } \\
\text { student socio- } \\
\text { economic } \\
\text { background }\end{array}$ & $\begin{array}{c}\text { Total variance } \\
\text { between schools } \\
\text { expressed as a } \\
\text { percentage of the } \\
\text { total variance } \\
\text { within the country }\end{array}$ & $\begin{array}{c}\text { Annual } \\
\text { expenditure } \\
\text { per student on } \\
\text { educational } \\
\text { core services } \\
\text { (below tertiary) } \\
2007\end{array}$ & $\begin{array}{l}\text { GDP per } \\
\text { capita }\end{array}$ & Gini Index \\
\hline & Score & S.E. & Score & S.E. & Score & S.E. & Score & S.E. & Score & S.E. & $\%$ & $\%$ & USD PPP & Value & Gini Index \\
\hline Brazil & 412 & (2.7) & 396 & (3.1) & $\underline{16^{3}}$ & (4.9) & 386 & (2.4) & 405 & (2.4) & 13 & 48 & $1796^{4}$ & 10770 & 0.57 \\
\hline Canada & 524 & (1.5) & 534 & $(1.6)$ & -10 & (3.4) & 527 & $(1.6)$ & 529 & $(1.6)$ & 9 & 22 & 7609 & 36397 & 0.30 \\
\hline Shanghai-China & 556 & (2.4) & $\mathrm{m}$ & $\mathrm{m}$ & $\mathrm{m}$ & $\mathrm{m}$ & 600 & $(2.8)$ & 575 & (2.3) & 12 & 38 & $42064^{5}$ & 5340 & 0.42 \\
\hline Hong Kong-China & 533 & (2.1) & $\mathrm{m}$ & $\mathrm{m}$ & $\mathrm{m}$ & $\mathrm{m}$ & 555 & $(2.7)$ & 549 & $(2.8)$ & 5 & 42 & $32896^{6}$ & 42178 & 0.43 \\
\hline Finland & 536 & (2.3) & 546 & $(2.6)$ & -11 & $(4.3)$ & 541 & $(2.2)$ & 554 & (2.3) & 8 & 9 & 6430 & 35322 & 0.26 \\
\hline Germany & 497 & (2.7) & 484 & (2.5) & $\underline{13^{3}}$ & (4.5) & 513 & (2.9) & 520 & $(2.8)$ & 18 & 60 & 7072 & 34683 & 0.27 \\
\hline Japan & 520 & (3.5) & 522 & $(5.2)$ & -2 & $(6.8)$ & 529 & (3.4) & 539 & $(3.4)$ & 9 & 49 & $8012^{4}$ & 33635 & 0.34 \\
\hline Singapore & 526 & (1.1) & $\mathrm{m}$ & $\mathrm{m}$ & $\mathrm{m}$ & $\mathrm{m}$ & 562 & (1.4) & 542 & (1.4) & 15 & 35 & $23699^{7}$ & 51462 & 0.42 \\
\hline Poland & 500 & (2.6) & 479 & (4.5) & $\underline{21^{3}}$ & $(5.8)$ & 495 & $(2.8)$ & 508 & (2.4) & 15 & 19 & 3784 & 16312 & 0.32 \\
\hline United States & 500 & (3.7) & 504 & $(7.0)$ & -5 & (8.3) & 487 & (3.6) & 502 & (3.6) & 17 & 36 & 9932 & 46434 & 0.36 \\
\hline United Kingdom & 494 & (2.3) & $\mathrm{m}$ & $\mathrm{m}$ & $\mathrm{m}$ & $\mathrm{m}$ & 492 & (2.4) & 514 & $(2.5)$ & 14 & 29 & 7032 & 34957 & 0.34 \\
\hline OECD average & 494 & $(0.5)$ & 497 & $(0.6)$ & -2 & $(2.7)$ & 497 & $(0.5)$ & 501 & $(0.5)$ & 14 & 39 & 6675 & 32962 & 0.31 \\
\hline
\end{tabular}

Values that are statistically significant are indicated in italics and underlined

1. OECD (2010b), PISA 2009 Results, Volumes 1-V, OECD Publishing

2. OECD (2010c). Education at a Glance 2010: OECD Indicators, OECD Publishing

3. Statistically significant.

4. Values for core and ancillary services.

5. Cumulative expenditure per student over the theoretical duration of primary studies (PISA 2009 Results).

6. Recurrent government expenditure on education, including primary, secondary and special education and departmental support (Hong Kong Annual Digest of Statistics 2010).

7. Cumulative expenditure per student for 5 to 15 -year-olds (PISA 2009 Results)

8. OECD average for 23 countries.

9. Gini index from the World Bank 1996

10. Gini index from the World Bank 1998

Source: OECD, PISA 2009 Database. 
Practices in the high-performing countries point to a strategy that entails the government making clear what standards of competencies students should achieve. Schools are given freedom in determining how to achieve these standards and are held accountable for the outcomes. Many states in the United States are well on the way to implementing common standards and competencies in the context of the Race to the Top (RTT) initiative. But to have a sustained impact on learning outcomes, further steps need to be taken to develop world-class standards for all the subjects in the core curriculum, not just language and mathematics.

The experience of high-performing countries has also demonstrated the benefits of a uniform, highquality school curriculum. A standardized curriculum could be developed using a process that brings together the best minds in the country, engaging subject matter experts and other stakeholders to produce well designed frameworks for what should be taught and when. A coordinated programme of instruction would also allow for greater diffusion of successful practices already in place in individual schools or localities. Policies to support such a process are already in place. For example, the Investing in Innovation Fund supports projects in primary and secondary school systems education that test, validate, and scale up promising strategies and interventions that raise overall student achievement, close the achievement gap, and improve outcomes for high-need students. Further efforts to inform educators and school systems of best practices are encouraged.

In this area, Canada can provide a solid benchmark for comparison. PISA test results show that Canada has both strong average results and less dispersion related to socio-economic status than many other nations. Yet, like the United States, Canada has a large, geographically dispersed, and culturally heterogeneous population and a highly decentralized educational system. Provincial governments in Canada are responsible for setting the curriculum, determining many major policies for schools, and providing most of the schools' funding. Within each of the provinces, responsibility is divided between the central provincial government and locally-elected school boards.

Part of the success of the Canadian educational system can be ascribed to the quality of its curriculum, which in turn is attributable to its development at the province level. Curriculum development is undertaken by the respective ministries of education. Through a process of extensive consultation with groups of teachers and subject matter experts, consensus is reached on what topics will be taught in what sequence through the grades. And at the national level, a Council of Ministers of Education (CMEC) exists as a forum through which the ministers of education in the respective provinces can meet for co-ordination purposes. Although its impact is somewhat limited given the country's decentralised educational structure, CMEC fulfils an important information-sharing function and enables good ideas and practices to spread across provincial lines.

Teachers also play a critical role in building a successful educational system. They need to be professionals, focused on quickly identifying students with learning difficulties and proposing pedagogical solutions for them. In high-performing countries, teachers are paid much more in relation to people with similar levels of qualifications than in the United States, and the teaching profession has high social status. As a result, these countries can recruit teachers from the top of the graduation distribution, not the bottom as in the United States. High-performing teachers interact with others in their schools to improve their teaching methods and master teachers are available to provide guidance. There are also teachers available to help bring students falling behind up to speed so that they can continue and succeed in mainstream classes. School heads also tend to be mentors in these countries rather than administrators, as in the United States.

Selecting, training and retaining excellent teachers are also necessary components to high-quality education. Additional money to pay teachers more could easily be found by reducing money spent on facilities and administrative overheads - on average, capital expenditure and overhead expenditure is a 
much higher share of total expenditure in US schools than in the high performing countries. Teachers could also be given more time to plan and improve their teaching by reducing their course hours and increasing class sizes, as Japan did. Class size has been shown to have a negligible effect on outcomes over a wide range of sizes.

To reduce the influence of socioeconomic background on US education outcomes, more resources need to be directed towards disadvantaged students. Currently, the United States is one of only three OECD countries (the other two are Israel and Turkey) that actually spend less per student on students from disadvantaged backgrounds than on other students. A key to redirecting resources towards students in most need would be to reform the local-property tax system of financing schools. This results in vast differences in resources per school, with schools in wealthy areas being well equipped and able to recruit the best teachers, while schools in poorer areas are in the opposite situation. This disparity reinforces the disadvantages of social segregation, which results in children in poorer schools having lower educational expectations and outcomes. Canada had similar arrangements but reformed them by moving school funding to the provincial level. In many other high-performing countries, the most able teachers work in the more socially disadvantaged schools, the opposite of what occurs in the United States.

The Administration has taken steps to promote many of these educational reforms, notably through the Race to the Top (RTT) programme. Launched in 2010, the RTT programme encourages US states to change their aspirations and organisational culture by: $i$ ) adopting internationally benchmarked statedeveloped standards and assessments that prepare students for success in college and the workplace; ii) recruiting, developing, rewarding, and retaining effective teachers and principals; iii) building data systems that measure student success and inform teachers and principals how they can improve their practices; and iv) turning around the country's lowest-performing schools (White House, 2012b; Office of Management and Budget, 2012). In addition, the work of the state consortia funded by RTT has generated important opportunities for the United States to make progress on adopting a consistent curriculum across school systems.

\section{Advance the skills of high school graduates with high-quality vocational training}

Every individual has different aptitudes, and many students will not go beyond a high school education. Although education should be about much more than preparation for work, the education system is a powerful tool for producing a globally competitive workforce. International evidence suggests that effective preparation for work entails success in academic courses, the acquisition of strong generic work skills - everything from showing up on time and putting in a good day's work to being an effective team member and working to meet deadlines - and technical competence in the job-specific skills needed to do the entry-level work in careers that pay well (OECD, 2011b). Countries vary widely in the degree to which they provide each of these bundles of skills and knowledge. In countries that do well on all three, youth unemployment tends to be lower, it takes less time for young people to get and keep good jobs, and economic competitiveness is higher, so there are strong reasons for a country to pay attention not just to the development of young people's academic skills and knowledge but to make sure it has a strong school-towork transition system (ibid).

In this context, the strong vocational component of the German educational system can provide a useful model for improving the earnings and participation of lower-skilled workers, particularly youth. Germany's secondary education follows a "dual" system, in which the two-thirds of students who enrol in the vocational tracks alternate between a few days in school and a few days at the workplace. In the company, the apprentice receives practical training which is supplemented by theoretical instruction in the vocational school. Around $60 \%$ of all young people learn a trade within the dual system of vocational education and training in Germany (UNESCO, 2009). There are around 350 state-recognised training occupations, such as carpentry, car mechanics and roofing. The period of training is usually two to 
three years and is concluded by a state examination. During this time, the apprentice is financially remunerated. Access to this training is not formally linked to a specific school certificate.

The German system is notable for its success in enabling young people from widely varying social backgrounds to integrate the learning of academic skills with the mastery of job-specific skills, so that students understand the theory behind the practice as they practice their generic work skills. The generic work skills, such as motivation, persistence, effort, discipline and interpersonal skills, are without doubt highly valued by employers. And for many students, this practice-based, highly applied style of learning is far more effective than studying classroom material without obvious applications to anything they know or care about. Some students only become engaged in course material when they see it actively put to use. Learning becomes necessary in order to solve the problems that these students find engaging. Problem-driven learning is the kind of learning most of us do when we leave school behind and enter the adult world. It is in this sense that the dual system is very much a part of the education system. Although students accept wages below the market level, they gain access to the possibility of employment with companies who might not otherwise be interested in hiring them. In short, they pay to gain important skills provided by their employers. Employers are increasingly willing to pay to send promising young people who come in through the dual system to university. In addition, OECD research suggests that workplace training facilitates recruitment of employees because potential employers and employees get the chance to get to know each other and apprentices make productive contributions such that employers benefit directly from the training (OECD, 2011b).

One might argue that the German educational system depends greatly on an industrial system that is very different from that of the United States, and thus is not easily transferable. But there is scope to provide American employers with incentives, such as payroll tax breaks or minimum wage exemptions, for offering apprenticeship programmes to youth. Pilot programmes could explore how to adapt Germany's effective school-to-work systems to the US context in ways that could produce major gains for employers, youth, and the educational system.

\section{Community colleges are a cost-effective means of raising human capital}

One particularly cost-effective approach to raising tertiary education attainment rates is to strengthen and enhance the community college system. Community colleges play an important role by providing an affordable, accessible opportunity to obtain postsecondary education. Unfortunately, many of the existing programs are under-utilised or under-resourced. Research has shown that rates of return for a community college degree are comparable to a degree from a four-year university, and yet Federal government funding for these programmes is currently modest, as most direct federal funding for higher education goes to public four-year colleges and universities (Greenstone and Looney, 2011).

Community colleges generally work with lean budgets; they are mainly funded by tuition, with some financial support provided by state and local governments. Moreover, budget pressures have greatly intensified in recent years given the sharp cutbacks in state and local government spending that were made in response to the economic downturn. The consequences of tight budgets can be quite costly for students, as capacity constraints mean that it often takes longer for students to complete the required courses. Studies have shown that the payoffs for a community college degree are greatest when studies are concentrated in more technical fields, but funding constraints mean that many community colleges cannot provide these technical degree programmes, because the development of these types of courses requires additional investments in lab or technology equipment. Most community colleges do not have the resources to provide career counselling to students or services that might help students identify a suitable field of study.

Local and regional business are a valuable and yet under-utilized resource to raise the returns to educational offerings at community colleges. Potential employers should be given more opportunities to 
provide input regarding their specific needs for skills and training, so that degree programmes and even individual courses can be tailored appropriately to the labour market. In addition, a combination of appropriate incentives and regulations could establish relationships among community colleges, regional technical schools, other post-secondary institutions, and employers that could expand opportunities for workplace training in the form of internships or shorter work placements. Efforts to encourage these types of programs have been proposed in the Administration's FY 2013 budget, which calls for USD 8 billion in funding for the Departments of Education and Labor to support state and community college partnerships.

\section{Raise completion rates by reducing financial and other barriers}

The value of post-secondary education would be increased by raising degree completion rates for tertiary education. These have gone up somewhat in recent years, but still only 58\% of full-time bachelor's degree-seeking students complete their degrees within six years of starting (U.S. Department of Education, National Center for Statistics). Completion rates are even lower for full-time students seeking certificates or associate degrees at two-year institutions - only $28 \%$ of students complete their programmes within $150 \%$ of the normal time. Completion rates for part-time students - which comprise $40 \%$ of tertiary students - are abysmal: The completion rates for bachelor's degrees (within eight years), associate degrees (within four years) and one-year certificates (within two years) are 24\%, 8\%, and 12\%, respectively (Complete College America, 2011).

For both full-time and part-time students, shorter and more rapid pathways to graduation would increase completion rates. The longer students take, the more that life pressures from work and family crowd out studying to complete tertiary qualifications. Shorter academic terms, less time off between terms and year-round scheduling would enable students to complete their studies more quickly. Measures to counter students wasting time on credits in excess of what is required for their programmes would also help.

One promising approach to increasing completion rates for part-time students is by helping them to reconcile work and study schedules. This can be done by scheduling courses in blocks, making it easier for students to work without missing courses. The City University of New York does this in its Accelerated Study in Associate Programs and achieves graduation rates three times higher than for its students who do not participate in the programme. Similarly, the 27 Tennessee Tech Centers achieve high graduation rates by enrolling students in whole academic programmes, rather than individual courses, in blocks of time that more easily accommodate students' work schedules. Greater use of online technology to reduce the amount of time that students need to spend in class would also help students reconcile study and other obligations.

Better academic preparation for tertiary education would also improve completion rates. Fully one half of those seeking a two-year associate degree require remedial education, with this proportion falling to $21 \%$ for those seeking a bachelor's degree (Complete College America, 2011). Students requiring remedial education have much lower completion rates than other students. Complete College America (2011) makes a variety of suggestions for reforming remedial education, notably by including students requiring remedial work into mainstream courses, while also providing them with intensive help to bring them up to speed. This is the approach to educating weaker school students that has been followed in Finland (and subsequently emulated in many other countries) with much success (OECD, 2011b).

Easing financial constraints faced by students could also help to increase tertiary graduation rates. Many individuals have difficulty financing their education because they need to support themselves and a family at the same time; furthermore, tuition has increased at an annual average real rate of $4 \%$ over the past three decades, outpacing family incomes and student loans by a considerable margin. Oliveira Martins et al (2007) find that easing liquidity constraints on students could increase the US graduation rate by 1.5 percentage points, which is one of the larger increases achievable in this way among OECD countries. 
The Administration has taken some measures recently to help students and their families pay for college it has increased Pell Grants and Congress extended until 2012 the American Opportunity Tax Credit - but such measures should be taken further. Students would also benefit greatly from an expansion in other types of assistance, such as child care and other family support services, which could be made available to students at reasonable cost.

\section{Disability programme reforms are needed to stem the tide of new enrolments}

As discussed in OECD Economic Survey of the United States (2007) and in the OECD Disability Study (2011), the large and increasing number of people receiving disability benefits through the Social Security Disability Insurance (SSDI) programme holds down labour utilisation and contributes significantly to reductions in labour force participation. In particular, the share of the working-age population between the ages of 20 and 64 enrolled in SSDI rose from 3.6\% in 1980 to $6.1 \%$ in 2007 and then to $6.6 \%$ in 2010 . Furthermore, increases in the number of applications for disability benefits are likely to continue for some time, since there is often a considerable lag between the rise in unemployment during a recession and an upward ratchet in disability rolls.

Figure 12. Disability rolls continue to trend up in the United States

Share of population receiving disability benefits

$\%$

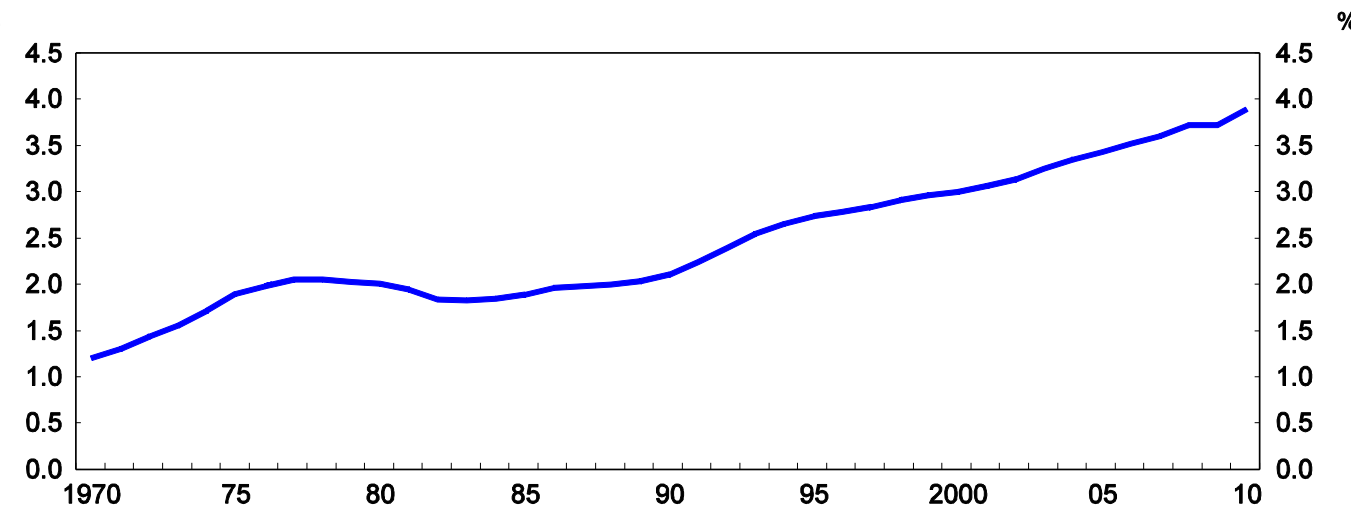

Note: Disability benefits refer to Social Security Disability Insurance.

Source: OECD, Sickness, Disability and Work, 2010 (Administrative data); OECD Population Statistics Database, 2012.

There are several factors behind the continued rise in disability rolls. According to Autor (2011), much of the increase in recent decades reflects a relaxation of eligibility restrictions that began in 1984 . New provisions made it easier for sufferers from back pain, arthritis and mental impairments to get benefits. Moreover, because these conditions tend to have early onset but low mortality, the expected duration of benefits lengthened from six years in 1983 to 14 years in 2004. Another important factor has been the increasing generosity of the programme. Disability beneficiaries receive heavily subsidised medical care, the relative value of which has increased substantially. In addition, key parameters in the formula determining benefits are indexed to average wages, which have increased faster than the wages of low-skilled workers. These factors have increased replacement rates, particularly at the bottom of the wage distribution and for workers without health insurance.

Changes in the US labour market over the past decades have also created new challenges for workers with disability. As discussed earlier, skill-biased technical change, off-shoring of low-skill activities, and other factors have reduced employment opportunities for workers at the low end of the skill distribution. These developments have affected people with disability disproportionately, since these individuals tend to 
have lower levels of education compared with the rest of the population. The recent deep recession and the persistent slack in the labour market have only aggravated the situation, since the evidence suggests that employment rates for workers with disability are more adversely affected during economic downturns. Burkhauser et al. (2001), for example, examined the relative outcomes of workers with disability over the business cycles of the 1980s and the 1990s in the United States and concluded that employment fell more for people with disability than for those without disability. As a result of these developments, disability benefits are increasingly taking on the role of a benefit of last resort for many working-age people facing labour market disadvantages and having difficulties in performing continuously at the expected high level of productivity.

Government reforms are clearly needed to stabilise and reduce the reliance on these programmes, particularly because almost none of the individuals who qualify for benefits ever return to the workforce. Although proposals to make disability benefits less generous have obvious political and economic difficulties, there seems to be scope for improving the targeting of benefits to those genuinely incapable of work. For example, Autor and Duggan (2006) propose greater reliance on independent medical evaluations and providing legal representation of the taxpayers' interest at appeals. They argue that these reforms would raise the rejection rate of non-deserving claims without hurting those in need.

Another area where reforms could potentially bring high returns is on the employer side. Autor and Duggan (2010) propose that a variety of so-called "front-end" approaches should be used to minimize movements of workers from employment into the SSDI system. The authors' suggestions include enhancements to workplace accommodation, rehabilitation services, and partial income support, with the common goal of enabling more workers with disabilities to remain in employment. In addition, financial incentives could be offered to employers that successfully accommodate workers who become disabled.

Reforms in the Netherlands can provide a useful model on both of these fronts, and the data on enrolments since their implementation illustrate that the effects of policy reforms can be large (Figure 13). In the early 2000s, the Netherlands conducted a major reform of its disability insurance system with the aim of reducing annual inflows into the programme by focusing benefits more effectively on those who could not work while strengthening the work incentives of those who could. Specific measures included tightening eligibility and testing criteria, extending the period of employer-paid sickness from one to two years, and introducing a "no-risk" policy where the government covers sickness payments for recently-hired partially disabled workers and of work-capacity related disability benefits to strengthen work incentives (OECD, 2008). 
ECO/WKP(2013)7

Figure 13. Disability enrolments in the Netherlands dropped noticeably following reforms

Share of population receiving disability benefits

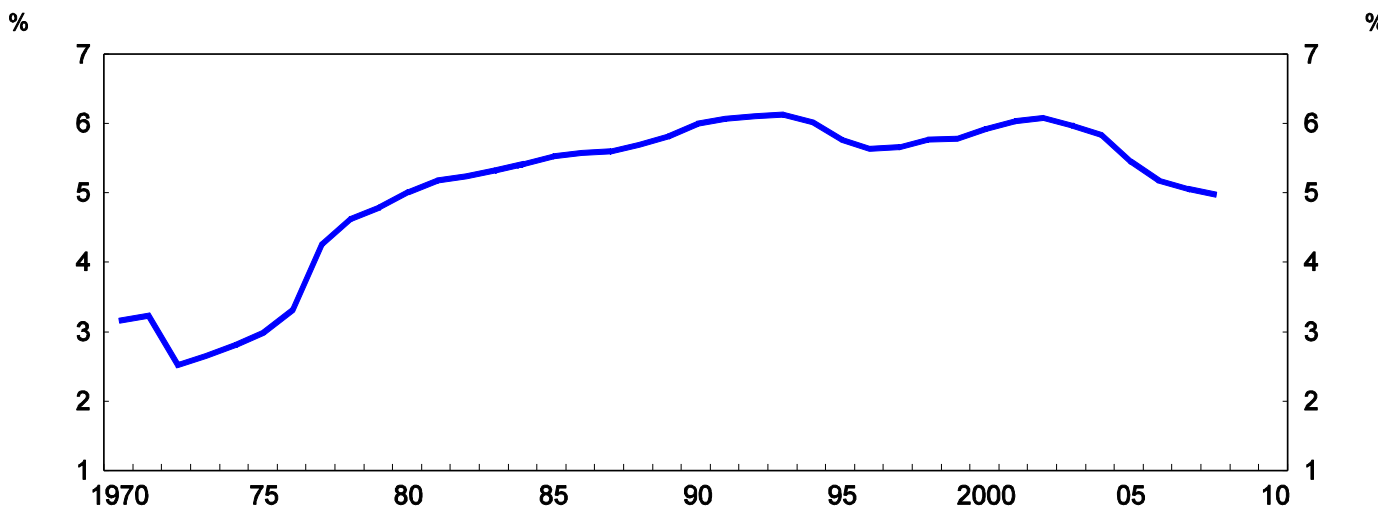

Note: Disability benefits refer to Social Security Disability Insurance

Source: OECD, Sickness, Disability and Work, 2010 (Administrative data); OECD Population Statistics Database, 2012

In the years immediately following the reform, both inflows into disability and the total number of claimants fell sharply. By 2008, the total stock of benefit recipients had fallen by roughly one-quarter from its 2002 peak. Estimates by Jehoel-Gijsbers (2007) suggest that the so-called "gatekeeper law" (greater employer responsibility for re-integration of sick employees) made the largest contribution to the overall fall in inflows (42\%), followed by a law lengthening employer-paid sick pay from one to two years (25\% to $35 \%$ ). There were also significant changes attributable to the restructuring of benefits and the reassessment of existing benefit recipients. In the early stages of this process, around $40 \%$ of those reassessed lost benefits altogether or were assigned to a lower category of disability; these initial reassessments focused on younger cohorts in the disability pool and on those most likely to be reintegrated.

\section{Box 3. Summary of recommendations for promoting job creation and earnings growth}

\section{Key recommendations:}

- Development of enhanced "activation" programmes would facilitate the return to work for many unemployed individuals and mitigate the risk of long-term unemployment becoming structural. A variety of proposals for training and re-employment services were presented in the Administration's FY 2013 budget, and these plans should be implemented without delay.

- Education and training are key to improving skills, reducing mismatches, and addressing the problem of slow wage growth. Programmes such as Race to the Top and measures to strengthen community colleges are steps in the right direction, but more could be done, such as reducing financial and other barriers to tertiary education and providing vocational training opportunities in secondary school.

\section{Other recommendations:}

- Strengthen and enhance the community college system, especially in technical fields and through collaboration with local employers.

- Offer high-quality vocational education in secondary schools with a substantial work-experience component, organised jointly with local employers.

- $\quad$ Reduce reliance on disability benefits by making eligibility requirements more stringent, and by enhancing workplace accommodations, rehabilitation services and partial income supports.

- Make social assistance programmes more responsive to economic conditions, so that more resources are allocated in tough economic times. 


\section{BIBLIOGRAPHY}

Aaronson, S., B. Fallick, A. Figura, J. Pingle, and W. Wascher (2006a), "The Recent Decline in the Labor Force Participation Rate and its Implications for Potential Labor Supply," Brookings Papers on Economic Activity, No. 1, pp. 69-134.

Aaronson, D., K-H. Park, and D. Sullivan. (2006b). "The decline in teen labor force participation," Economic Perspectives, Federal Reserve Bank of Chicago, issue 2006Q1, pp. 2-18.

Aaronson, D., B. Mazumder, and S. Schechter (2010), "What is behind the rise in long-term unemployment?” Economic Perspectives, Federal Reserve Bank of Chicago, issue 2010Q2, 28-51.

Autor, D. H. (2011), "The Unsustainable Rise of the Disability Rolls in the United States: Causes, Consequences, and Policy Options", MIT working paper, November 23, 2011.

Autor, D. H. and Mark Duggan (2006), "The Growth in the Social Security Disability Rolls: A Fiscal Crisis Unfolding” Summer 2006, Journal of Economic Perspectives, 20(3), Summer 2006, 71-96.

Autor, D. H. and Mark Duggan (2010), "Supporting Work: A Proposal for Modernizing the U.S. Disability Insurance System”, Center for American Progress and The Hamilton Project, December 2010.

Barnichon, R. (2010), “Building a Composite Help-Wanted Index”, Economics Letters, Vol. 109 (December), pp. 175-78.

Blanchard, O. J. and P. Diamond (1994), "Ranking, Unemployment Duration, and Wages", Review of Economic Studies, 61(3), pp. 417-34.

Burkhauser, R., M. Daly, A. Houtenville and N. Nargis (2001), "The Employment of Working-Age people with Disabilities in the 1980s and 1990s: What current data can and cannot tell us", Working Paper in Applied Economic Theory, No. 2001-20, Federal Reserve Bank of San Francisco.

Card, D., T. Lemieux and W. C. Riddell (2004), "Unionization and Wage Inequality: A Comparative Study of the US, the UK, and Canada", NBER Working Paper, No. 9473.

Card, D., J. Kluve and A. Weber (2009), "Active Labor Market Policy Evaluations: A Meta-Analysis”, IZA Discussion Paper, No. 4002, Bonn.

Chan, S. (2001), “Spatial Lock-in: Do Falling House Prices Constrain Residential Mobility?”, Journal of Urban Economics, 49(1), 567-586.

Complete College America (2011), Time is the Enemy - the surprising truth about why today's college students aren't graduating...AND WHAT NEEDS TO CHANGE, 2011 National Report.

Davis, S.J. and T. von Wachter (2011), "Recessions and the Costs of Job Loss", Brookings Papers on Economic Activity, No. 2, pp. 1-72. 
Dickert-Conlin, S., and D. Holtz-Eakin. (2000). "Employee-Based Versus Employer-Based Subsidies to Low-Wage Workers: A Public Finance Perspective". In Finding Jobs: Work and Welfare Reform, eds. D. E. Card and R. M. Blank. New York: Russell Sage Foundation, pp. 262-94.

Estevão, M. and E. Tsounta (2011), "Has the Great Recession Raised U.S. Structural Unemployment?" IMF working paper, May 2011.

Elsby, M., B. Hobijn, and A. Sahin (2010), “The Labor Market in the Great Recession”, Brookings Papers on Economic Activity, Spring 2010, pp. 1-48.

Figura, A. and W. Wascher (2010), "The Causes and Consequences of Sectoral Reallocation: Evidence from the Early 21st Century”, Business Economics, Vol. 45, No. 1, pages 49-66.

Goldin, C., and L. F. Katz (2008), The Race between Education and Technology, Harvard University Press, Cambridge, Massachusetts.

Greenstone, M. and A. Looney (2011), "Building America's Job Skills with Effective Workforce Programs: A Training Strategy to Raise Wages and Increase Work Opportunities", Strategy Paper for The Hamilton Project, November 2011.

Guichard, S. and Rusticelli, E. (2011) "Reassessing the NAIRUs after the Crisis" OECD Economics Department Working papers No. 918, OECD Publishing.

Haltiwanger, J. (2011) "Job Creation and Firm Dynamics in the U.S.", University of Maryland working paper, College Park, Maryland.

Haskins, R. (2011), “Fighting Poverty the American Way”, paper prepared for conference on Anti-Poverty Programs in a Global Perspective: Lessons from Rich and Poor Countries, June 2011.

Hotchkiss, J. (2009), "Decomposing Changes in the Aggregate Labor Force Participation Rate", Federal Reserve Bank of Atlanta working paper 2009-6a.

Jacobson, L., R. LaLonde, and D.G. Sullivan (2005), "Estimating the returns to community college schooling for displaced workers", Journal of Econometrics, Elsevier, Vol. 125(1-2), pp 271-304.

Jehoel-Gijsbers, G. (2007), "Beter aan het werk. Trendrapportage ziekteverzuim, arbeidsongeschiktheid en werkhervatting", Social and Cultural Planning Bureau, The Hague.

Johnson, D., J. Parker, and N. Souleles, "Household Expenditure and the Income Tax Rebates of 2001", American Economic Review, Vol. 96, No. 5 (December 2006), pp. 1589-1610.

Karahan, F. and S. Rhee (2011), "Geographical Reallocation and Unemployment during the Great Recession: The Role of the Housing Bust", University of Pennsylvania working paper.

Krueger, A. B. and A. Mueller (2011), "Job Search, Emotional Well-Being, and Job Finding in a Period of Mass Unemployment: Evidence from High-Frequency Longitudinal Data", Brookings Papers on Economic Activity, Spring 2011.

Mortensen, D. and C. Pissarides (1994), "Job Creation and Job Destruction in the Theory of Unemployment", The Review of Economic Studies", Oxford University Press, Vol. 61, No. 3 (Jul., 1994), pp. 397-415. 
Molloy, R., C. Smith, and A. Wozniak (2011), "Internal Migration in the United States", Federal Reserve Board Finance and Economics Discussion Series, 2011-30.

Neumark, D. (2011). "Policies to Encourage Job Creation: Hiring Credits vs. Worker Subsidies". NBER Working Paper 16866

OECD (2006), OECD Employment Outlook 2006, OECD Publishing, Paris.

OECD (2007), OECD Employment Outlook 2007, OECD Publishing, Paris.

OECD (2008), Sickness, Disability and Work: Breaking the Barriers (Vol. 3), Denmark, Finland, Ireland and the Netherlands, OECD Publishing, Paris.

OECD (2009), The Political Economy of Reform, OECD Publishing, Paris.

OECD (2010a), OECD Employment Outlook 2010, OECD Publishing, Paris.

OECD (2010b), PISA 2009 Results, Volumes I-V, OECD Publishing, Paris.

OECD (2010c), Education at a Glance 2010: OECD Indicators, OECD Publishing, Paris.

OECD (2010d), The High Cost of Low Educational Performance, The Long-Run Impact of Improving PISA Outcomes, OECD Publishing, Paris.

OECD (2011a), OECD Employment Outlook 2011, OECD Publishing, Paris.

OECD (2011b), Lessons from PISA for the United States, Strong Performers and Successful Reformers in Education, OECD Publishing, Paris.

Office of Management and Budget (2012), Fiscal Year 2013 Budget of the U.S. Government.

Oliveira Martins, J., R. Boarine, H. Strauss, C. de la Maisonneuve and C. Saadi (2007), “The Policy Determinants of Investment in Tertiary Education", OECD Economics Department Working Paper No. 576.

Parker, J., N. Souleles, D. Johnson, and R. McClelland (2011), "Consumer Spending and the Economic Stimulus Payments of 2008”, Working Paper 16684 (Cambridge, MA: National Bureau of Economic Research).

Pavetti, L. and L. Schott (2011), “TANF's Inadequate Response to Recession Highlights Weakness of Block-Grant Structure", Center on Budget and Policy Priorities, 14 July .

Rothstein, J. (2011), “Unemployment Insurance and Job Search in the Great Recession”, Brookings Papers on Economic Activity, Fall.

Smith, C. (2011), "Polarization, immigration, education: What's behind the dramatic decline in youth employment?", Finance and Economics Discussion Series, Federal Reserve, 2011-41.

Sullivan, D. and T. von Wachter (2009), "Job Displacement and Mortality: An Analysis Using Administrative Data", Quarterly Journal of Economics, Vol. 124, No. 3, pp. 1265-1306. 
UNESCO Institute of Statistics (2009), Global Education Digest, 2009: Comparing Education Statistics Across the World, UNESCO, Paris.

U.S. Department of Education, National Center for Education Statistics, Integrated Postsecondary Education Data System (IPEDS), Spring 2003 and Spring 2011, Graduation Rates and Institutional Characteristics components.

Van Zandweghe, W. (2012), “Interpreting the Recent Decline in Labor Force Participation”, Economic Review, Federal Reserve Bank of Kansas City, 2012:Q1, pp. 5-34.

White House (2011), American Jobs Act of 2011, legislative proposal submitted to Congress, September 12, 2011, Washington, DC.

White House (2012a), The White House Announces Details on President's Plan to Provide Americans with Job Training and Employment Services, March 12, 2012, White House and Department of the Treasury, Washington, DC.

White House (2012b), 2012 Economic Report of the President, Washington, DC. 


\section{WORKING PAPERS}

The full series of Economics Department Working Papers can be consulted at www.oecd.org/eco/workingpapers/

1014. Why do Russian firms use fixed-term and agency work contracts?

(January 2013) by Larisa Smirnykh and Andreas Wörgötter

1013. The Equity implications of fiscal consolidation

(January 2013) by Lukasz Rawdanowicz, Eckhard Wurzel and Ane Kathrine Christensen

1012. The Dutch labour market: preparing for the future (January 2013) by Mathijs Gerritsen and Jens Høj

1011. Reforming policies for the business sector to harvest the benefits of globalisation in the Netherlands

(January 2013) by Mathijs Gerritsen and Jens Høj

1010. Health care reform and long-term care in the Netherlands (January 2013) by Erik Schut, Stéphane Sorbe and Jens Høj

1009. Enhancing the inclusiveness of the labour market in Belgium (January 2013) by Jens Høj

1008. Reducing poverty in Estonia through activation and better targeting (December 2012) by Sarah Flèche and Artur Radziwill

1007. Matching skills and jobs in Estonia

(December 2012) by Lilas Demmou

1006. Debt and macroeconomic stability: An overview of the literature and some empirics (December 2012) by Douglas Sutherland and Peter Hoeller

1005. Debt and macroeconomic stability: Debt and the business cycle (December 2012) by Volker Ziemann

1004. Debt and macroeconomic stability: Case studies (December 2012) by Rossana Merola

1003. Debt and macroeconomic stability

(December 2012) by Douglas Sutherland, Peter Hoeller, Rossana Merola and Volker Ziemann

1002. Reducing greenhouse gas emissions in a cost effective way in Switzerland.

(December 2012) by Anita Wölfl and Patrizio Sicari

1001. Strengthening innovation in the United States

(November 2012) by David Carey, Christopher Hill and Brian Kahin

1000. Long-term growth scenarios

(January 2013) by Åsa Johansson, Yvan Guillemette, Fabrice Murtin, David Turner, Giuseppe Nicoletti, Christine de la Maisonneuve, Philip Bagnoli, Guillaume Bousquet and Francesca Spinelli 
999. Selected aspects of household savings in Germany - evidence from micro-data

(November 2012) by Christina Kolerus, Isabell Koske and Felix Hüfner

998. Improving the tax system in Indonesia

(November 2012) by Jens Arnold

997. Unleashing business innovation in Canada

(November 2012) by Alexandra Bibbee

996. Public policy and resource allocation: evidence from firms in OECD countries

(October 2012) by Dan Andrews and Federico Cingano

995. Promoting SME development in Indonesia

(October 2012) by Annabelle Mourougane

994. Portugal: Rebalancing the economy and returning to growth through job creation and better capital allocation.

(October 2012) by Álvaro Pina and Ildeberta Abreu

993. Public debt, economic growth and nonlinear effects: Myth or reality?

(October 2012) by Balázs Égert

992. Choosing the pace of fiscal consolidation

(September 2012) by Lukasz Rawdanowicz

991. Tertiary education developing skills for innovation and long-term growth in Canada

(September 2012) by Calista Cheung, Yvan Guillemette and Shahrzad Mobasher-Fard

990. Trade and product market policies in upstream sectors and productivity in downstream sectors:

firm-level evidence from China

(September 2012) by Maria Bas and Orsetta Causa

989. Intangible assets, resource allocation and growth: a framework for analysis

(September 2012) by Dan Andrews and Alain de Serres

988. Current account benchmarks for Turkey

(September 2012) by Oliver Röhn

987. Structural reforms to boost Turkey's long-term growth

(September 2012) by Rauf Gönenç, Oliver Röhn, Vincent Koen and Şeref Saygili

986. Tackling Turkey's external and domestic macroeconomic imbalances

(September 2012) by Oliver Röhn, Rauf Gönenç, Vincent Koen and Ramazan Karaşahin

985. Portugal: Solid foundations for a sustainable fiscal consolidation

(September 2012) by David Haugh and Stéphane Sorbe 